\title{
Editorial
}

Introduction to Section 1:

\section{The History of East European Feminisms Revisited}

\author{
Maria Bucur ${ }^{1 *}$, Krassimira Daskalova ${ }^{2 *}$
}

Published: September 8, 2020

Historians of East European feminisms have been busy over the past thirty years. Though some interest in this topic began to develop in the 1970s, it did not become a robust field of research until the 1990s, when it took off all over the post-communist world. ${ }^{1}$ Thirty years later, scholars in this field have become fully interconnected with other important contemporaneous trends in feminist historiography, especially in the area of transnational movements and in the framework of entangled history. This forum features some of the newest research projects of scholars primarily from the region, with pieces that feature case studies linked both to Turkey, Serbia/Yugoslavia, Bulgaria, Russia, and the Ukraine, as well as to international networks such as the International Woman Suffrage Alliance (IWSA), the Women's International League for Peace and Freedom (WILPF), and the Little Entente of Women (LEW).

Women's and gender history developed as an academic field during the 1970s first in the USA and Western Europe and later on, mostly after 1989, in Central, Eastern and Southeastern Europe. ${ }^{2}$ During the first couple of decades this scholarship, especially the history of women's movements and feminisms, was confined within narrow national frames that map onto the major tendencies of the mainstream historiography since the nineteenth century. Many historians still continue to work within this paradigm, neglecting the great interconnectedness of the ideas, strategies and activities used by women's activists across political borders.

Recently new directions have emerged, most notably transnational and global history, focusing especially on personalities and ideas, as well as actions and practices that transgress the fixed borders of the nation-state. One dimension of transnational history is 'entangled history'. Varieties of this approach have grown in French and German language scholarship under the terms 'bistoire croisée' and 'Verflechtungsgeschichte'. The methodology of entangled history is complex, multidimensional and adds new layers of analysis to transnational history, most importantly mutual formation and self-reflexivity. New publications in this vein have analysed the transfer of ideas and practices (Espagne and Werner, 1988; Espagne, 1999), the entangled history of colonisers and colonised societies (Randeria, 1999; Conrad and Randeria, 2002), as well as relations between France and Germany and other contexts (Werner and Zimmermann, 2002, 2003, 2006).

These new approaches address the dynamic aspects and mutual influences of women's activism in a more comprehensive, multidimensional way that renders visible the agency of various actors significant for the advancement or limitations in women's emancipation. Scholars who choose to frame their research in this matter

1 The most important initial transnational effort in facilitating the development of this field was the work on and publication of the Biographical Dictionary of Women's Movements and Feminisms: Central, Eastern, and South Eastern Europe, 19th and 20th Centuries (De Haan, Daskalova, and Loutfi, 2006), and the publication of the journal Aspasia. The International Yearbook of Central, Eastern and Southeastern Women's and Gender History.

${ }^{2}$ See some of the first reflections on the topic by Maria Bucur (Bucur, 2008) and the two forums published in Aspasia. The International Yearbook of Central, Eastern and Southeastern European Women's and Gender History (Daskalova, 2012; Daskalova, 2013). The participants include: Maria Bucur on Romania; Krassimira Daskalova on Bulgaria; Gabriela Dudekova on Slovakia; Eleni Fournaraki and Yannis Yannitsiotis on Greece; Biljana Kašc and Sandra Prlenda on Croatia; Oksana Kis on Ukraine; Dalia Leinarte on Lithuania; Ivana Pantelic and Biljana Dojcinovic on Serbia; Enriketa Papa-Pandelejmoni and Gentiana Kera on Albania; Natalia Pushkareva on Russia; Grazyna Szelagowska on Poland; Sirin Tekeli on Turkey; Ester Varsa (Daskalova, 2013) and Susan Zimmermann (2014) on Hungary; Sabina Znidarsic Zagar and Nina Vodopivec on Slovenia.

${ }^{1}$ John V. Hill Professor of East European History and Gender Studies at Indiana University, Bloomington, USA ${ }^{2}$ Professor of Modern European Cultural History at Sofia University, St. Kliment Obridski, Sofia, BULGARIA

*Corresponding Authors: mbucur@indiana.edu, daskalova@phls.uni-sofia.bg 
open up new possibilities for understanding the connections and interactions among individual women's activists and women's networks and the exchanges and entanglements between the national, regional and wider international women's organisations. Among these scholarly interventions is the inspiring pioneering work by Francisca de Haan on women's movements and feminisms, which emphasises the importance of 'mutual shaping' and 'self-reflexivity' of feminist entangled and transnational history for understanding the longue-durée transnational links between individual women and women's groups and the border crossings of ideas, agendas, solidarities and actions (De Haan, 2017). These novel approaches present great potential and promise considerable yield if applied to women's activism in Eastern Europe. The interview with De Haan at the end of the special section features further insights from the Dutch historian on current projects in this area. She outlines her recent work on the entangled histories of women's movements and feminisms by paying attention to the activities of the 'big three' international women's networks in the post-1945 world: the International Council of Women (ICW), the International Woman Suffrage Alliance (IWSA, which later became: International Alliance of Women, IAW) and the Women's International Democratic Federation (WIDF).

Our Special Section in Feminist Encounters sought contributions on the history of East European feminisms from a transnational and entangled perspective, asking contributors to focus specifically on contacts and activities of feminists that crossed national borders physically or symbolically. Our definition of Eastern Europe encompasses Russia, the USSR and its European successor states, the Habsburg Empire and its successor states, and the Balkans, inclusive of Turkey and the Ottoman Empire. Starting at the end of the nineteenth century, a number of large international women's networks were established, among them the ICW, the IWSA, ${ }^{3}$ the Women's International League for Peace and Freedom (WILPF), and the WIDF, to name some of the most active and long lasting among them. An important regional East European organisation, the Little Entente of Women (LEW), was established in 1923 as an off-shoot of the IWSA. Unsurprisingly, the LEW followed the aims and goals of the IWSA, yet at the same time developed its own agenda relevant to the unresolved problems of the East European women's movements which were part of LEW. Through its connection with IWSA the LEW also educated feminists from other countries about the legislation, policies and other non-governmental activities happening in this part of Europe, providing ideas for women's activists in other parts of the world.

With this special section we want to highlight some of the hidden links and entanglements between East European and other feminist movements by paying attention to major actors in international networks who came from Eastern Europe and the transfer of ideas and agendas between the international and regional, national or local women's movements and feminisms. Overall, we were eager to receive pieces that included both deep engagement with specific and relatively unknown historical sources (of any nature and up to the present), as well as analyses of specific transnational aspects of East European feminisms. For scholars interested in submitting pieces focusing on the post-communist period in particular (or very recent history, more generically), we were willing to consider discussions of current issues, but with a historical component in terms of the contextualisation and analysis. While the Anglocentric periodisation of feminist waves has already been contested many times in the scholarship on feminisms, we wanted to test some lesser known theoretical models of feminisms, such as Karen Offen's typology of the individualist and relational feminist arguments throughout Europe between the early eighteenth and mid-twentieth century (Offen, 2000). This proved to be a promising framework for some authors, while others were interested in critical perspectives that engage differently with the development of feminisms in Eastern Europe.

During the long nineteenth century, feminist organisations based on national (and sometimes clearly ethnonationalist) self-affiliation sprang up in Eastern Europe. By the end of the nineteenth century, socialist women's organisations also began to appear in this region. Many of these Eastern European feminists and organisations joined major transnational networks such, as ICW, IWSA, WILPF. These international organisations presented an opportunity for feminist activists from Eastern Europe; they used their participation to lend weight to their domestic demands, as well as to promote, among other things, their nationalist agendas internationally. This strengthened the 'duality' of these women's networks, prompting some historians to call them 'inter/national' (Zimmermann, 2005: 87-117; Sluga, 2013). Building on that, we wanted to pay attention to the role and exchanges of some of the most dynamic organisations and their activists who were members of the governing bodies of the above-mentioned international organisations: Alexandrina Cantacuzino from Romania, Avra Teodoropoulou from Greece, Dimitrana Ivanova from Bulgaria, Františka Plamínková from Czechoslovakia, and Milena Atanacković from Serbia/Yugoslavia.

From the nineteenth and long into the twentieth century, Eastern Europe witnessed the transition of traditional collectivistic peasant societies into more open, dynamic and individualistic bourgeois cultures. This modernisation process introduced not only a new, urban material culture but also new intellectual tropes, such as the spread of Enlightenment, Romantic nationalism and liberal ideas. Many among the burgeoning local intelligentsia and

\footnotetext{
${ }^{3}$ Renamed the International Alliance of Women for Suffrage and Equal Citizenship, IAWSEC, in 1926 and subsequently the International Alliance of Women, IAW.
} 
political elites embraced concepts such as freedom, progress, emancipation of the human spirit, development of universal law and morality and rational organisation of everyday public life, even as the 'nation' as an organic being with both biological and cultural attributes was also becoming a related favoured trope. In a context of so many significant and rapid changes, there are some similarities, but also substantial differences among East European societies.

The 'woman question' became an early trope across the region to engage critically with traditional gender norms and the position of women in these societies in transition. Starting in the mid-nineteenth century, the adoption of versions of the Napoleonic Code as a model for civil codes in the emerging nation-states of the Balkans created a new legal framework for enacting patriarchy and gender discrimination. In other Eastern European states with a multi-national character, like Austria-Hungary and Russia, versions of the Napoleonic Code also became the modern version of those states' civil law. Women's groups developed in part as partners to men in the modernisation process and in part as critics of the laws and other gendered structures being put in place, such as women's exclusion from most professions and the suffrage.

Modernisation, especially in the new nation-states of the region, was accompanied by the gradual extension of literacy to a practically universal ability to read and write in the second half of the twentieth century. In this context, however, women's education was less developed and as a result, the literacy rate among women did not reach $100 \%$ until a generation after the communist takeover. By contrast, most men were already literate by the beginning of World War II, with substantial differences between the urban population (with a much higher literacy rate in all East European countries) and the rural population, where male literacy was significantly lower, though not as low as female rates. In addition to gender inequalities, many other variables across Eastern Europe-from ethnic and religious to economic and political—-render the region difficult to characterise as having unitary characteristics.

In the late nineteenth century, small groups of women in Turkey, Bulgaria, Russia, and Serbia, dedicated to the social, economic and eventually political emancipation of female citizens in their respective countries began to draw comparisons between their own situation and that of women elsewhere. They found echoes of their own questions and ideas for how to reconsider inequalities in their own societies among international networks of women in England and elsewhere in Europe. By the same token, the British, French, and other feminists with whom these early women activists came into contact with also began to take interest in, and at times draw inspiration from what they saw happening in Eastern Europe. For instance, as Asli Davaz shows in her contribution, the interviews and reports published by Cécile Brunschvicg after her trip through the region served not just to familiarise the international public with people and organisations active in Eastern Europe, already an extremely useful dissemination of information. In addition, her reports described initiatives happening in the region, such as The Woman's House in Bucharest, which could become a model for similar activities in France, where there was a need for such an institution, as far as Brunschvicg believed.

Women's magazines became a vehicle for circulating ideas about women's emancipation, feminism and the 'New Woman' in East Europe in the last quarter of the nineteenth century. It became an integral part of both 'imagining the nation', as well as constructing a cultural literacy of modernity that implicitly called into question existing gender norms. Women, especially those who had the privilege of an education and thus tended to be from the socio-economic elites of their countries, together with their male feminist allies, started to raise their voices against patriarchal control, calling for better access to education, questioning women's socio-economic powerlessness and emphasising the spiritual equality between men and women in order to advocate for women's full rights as citizens of their newly established countries. These publications provide important correctives to assumptions among some scholars about the 'critical period of national formation' and demonstrate the differential integration of women and men into the national project (Walby, 1992: 81-100). Gender norms played an active role in how men and women came to see their specific relationships with modern citizenship, giving rise to both alliances and tensions between male and female proponents of modernisation, as the contributions by Irina Yukina and Ana Kolarić show. As their analyses also demonstrate, feminist editors made strategic choices in presenting these tensions on the pages of their journals through the voice of foreign, especially British feminists. By carefully couching those more radical and progressive ideas as 'foreign', an editor aspiring to bring over readers of various stripes of nationalist and feminist inclinations provided a comfortable framework for presenting in acceptable terms what might have otherwise been considered discomforting ideas.

Women's periodicals had different aims and agendas, trying to capture a small, but quickly evolving readership. The ones presented here can be divided into two major groups: 1) Openly feminist newspapers and journals, aimed primarily at the civic education of their female readers and at turning them into conscious, active citizens and professionals, using self-conscious feminist tropes and vocabulary (e.g., describing the achievements of prominent female professionals across Europe as an example of what was possible at that time for women to imagine for themselves); and 2) Women's popular magazines, aimed at a broader female readership, which sought to modernise behaviour and thinking through smaller measures of personal emancipation—such as modern cooking, house management, sowing and parenting. While three of the contributions to this special section focus on the former 
(Yukina, Kolarić, Isidora Grubacki), one article focuses on the latter (Valentina Mitkova), providing an important counterpoint to the former. One of the enhancements of entangled transnational history is to better highlight hidden forms of intellectual and political networking. Feminist journals provided ideas for action in the public sphere. The women's magazines described in Mitkova's essay became a conduit for reshaping gender norms and enhancing women's authority in the private sphere. The analysis of these journals presents us with the unambiguous conclusion that the work middle class and elite women were doing in parts of Western Europe was visible and of concern to their East European counterparts. Furthermore, even though on occasion East European feminists embraced the trope of 'tradition' to separate themselves from other varieties of feminist thinking and activism, they were not 'backward,' even when they claimed to be so. They were part of a larger transnational evolving network of similar, contemporaneous aspirations. In fact, the Russian feminists present at the birth of the Bolshevik Revolution helped usher in the most progressive comprehensive policies for women's emancipation than any other state in the world for decades to come.

Sandra Russell's piece is somewhat different in focus than the other pieces, but offers a useful counterpoint to those contributions. Russell takes us inside the world of female Ukrainian writers and provides a close reading of how not just explicitly feminist journals and women's magazines, but women's poems become a vehicle for expressing feminism and nationalism when censorship (such as the one experienced by Ukrainian writers under the Soviet regime) became the mandatory framework for the written word. The piece reminds us that, while the Soviet Union was an early and inspiring experiment in women's emancipation, by the 1960s it had become a prison for many who did not self-identify with its version of 'friendship among the nations' and of 'equality'. Taking us through the work of three generations of female Ukrainian poets, Russell shows us their development: initially timid but eventually more expressive and forceful in their feminist voices that at times have nationalist undertones and at times are simply apocalyptic, especially when reflecting on the aftermath of the Chernobyl nuclear disaster.

Overall, all contributions offer original and insightful points of entry for scholars of feminist movements since the late nineteenth century, whether focusing on East Europe or other parts of the world. They invite us to think about the transnational and mutually constitutive connections that activists, writers and publishers of women's periodicals brought about across Europe and beyond. Hopefully they will also encourage us to think about the circulation of feminist ideas and policies in more than one direction, so that concepts such as 'influence' become understood in a multi-directional sense, rather than just as a 'West and the rest' phenomenon.

\section{REFERENCES}

Bucur, M. (2008). An archipelago of stories: Gender history in Eastern Europe, The American Historical Review, 113(5), 1375-1389.

Conrad, S. and Randeria, S. (2002). Einleitung: Geteilte Geschichten - Europa in einer postcolonialen Welt. In Conrad S. and Randeria, S. (eds.). Jenseits des Europazentrismus. Postkoloniale Perspektiven in den Geschichts- und Kulturwissenschaften (pp. 9-49). Frankfurt and New York: Campus Press.

Daskalova, K. (ed.). (2012). Clio on the margins. Women's and gender history in Central, Eastern and Southeastern Europe. Part One, Aspasia. The International Yearbook of Central, Eastern and Southeastern European Women's and Gender History, 6, 125-185.

Daskalova, K. (ed.). (2013). Clio on the margins. Women's and gender history in Central, Eastern and Southeastern Europe. Part Two, Aspasia. The International Yearbook of Central, Eastern and Southeastern European Women's and Gender History, 7, 132-213.

De Haan, F. (2017). Writing inter/transnational history: The case of women's movements and feminisms. In Haider-Wilson, B., Godsey, W. D. and Mueller, W. (Hgg./Eds). Internationale Geschichte in Theorie und Praxis? International History in Thery and Practice. Sonderdruck (pp. 501-536). Vienna: Austrian Academy of Sciences Press.

De Haan, F., Daskalova, K. and Loutfi, A. (eds.) (2006). A Biographical Dictionary of Women's Movements and Feminisms: Central, Eastern, and South Eastern Europe, 19th and 20th centuries. Budapest: Central European University Press.

Espagne, M. and Werner, M. (eds.). (1988). Transferts culturels. Les relations interculturelles dans l'espace franco-allemand (XVIIIe-XXe siècles). Paris: Éditions Recherche sur les civilisations.

Espagne, M. (1999). Les transferts culturels franco-allemands, Paris: PUF.

Offen, K. (2000). European Feminisms, 1700-1950. A political history. Stanford, CA: Stanford University Press.

Randeria, S. (1999). Geteilte Geschichte und verwobene Moderne. In Rüsen, J., Leitgeb, H., and Jegelka, N. (eds.). Zukunfsentwürfe: Ideen für eine Kultur der Veränderung (pp. 87-96). Frankfurt and New York: Campus Press.

Sluga, G. (2013). Internationalism in the Age of Nationalism. Philadelphia: University of Pennsylvania Press.

Walby, S. (1992). Woman and nation, International Journal of Comparative Sociology, 33(1-2), 81-100.

Werner, M. and Zimmermann, B. (2002). Vergleich, Transfer, Verflechtung. Der Ansatz der Histoire croisée und die Herausforderung des Transnationalen, Geschichte und Gesellschaft, 28(4), 607-636. 
Werner, M. and Zimmermann, B. (2003), Penser l'histoire croisée: Entre empirie et réflexivité, Annales: Histoire, Sciences Sociales, 58(1), 7-36.

Werner, M. and Zimmermann, B. (2006) Beyond comparison: Histoire croisée and the challenge of reflexivity, History and Theory, 45, 30-50.

Zimmermann, S. (2005). The challenge of multinational empire for the International Women's Movement: The Habsburg Monarchy and the development of the feminist inter/national politics, Journal of Women's History, 17, 87-117.

Zimmermann, S. (2014). In and out of the cage. Women's and gender history written in Hungary in the statesocialist period, Aspasia. The International Yearbook of Central, Eastern and Southeastern European Women's and Gender History, 8, 125-149.

Citation: Bucur, M. and Daskalova, K. (2020). The History of East European Feminisms Revisited. Feminist Encounters: A Journal of Critical Studies in Culture and Politics, 4(2), 23. https://doi.org/10.20897/femenc/ 8511

Copyright (C) 2020 by Author/s and Licensed by Lectito BV, Netherlands. This is an open access article distributed under the Creative Commons Attribution License which permits unrestricted use, distribution, and reproduction in any medium, provided the original work is properly cited. 